\title{
NF-кB activity in distinct neural subtypes of the rat hippocampus: Influence of time and GABA antagonism in acute slice preparations
}

\author{
Graham K. Sheridan, ${ }^{1}$ Mark Pickering, ${ }^{1}$ Clare Twomey, ${ }^{1}$ Paul N. Moynagh, ${ }^{2}$ \\ John J. O'Connor, ${ }^{1}$ and Keith J. Murphy',3 \\ ${ }^{1}$ Applied Neurotherapeutics Research Group, UCD School of Biomolecular and Biomedical Science, Conway Institute, University \\ College Dublin, Belfield, Dublin 4, Ireland; ${ }^{2}$ Institute of Immunology, Department of Biology, National University of Ireland, \\ Maynooth, Co. Kildare, Ireland
}

\begin{abstract}
Hippocampal memory-associated synaptic plasticity is driven by a cascade of transcription and new protein synthesis. In vitro electrophysiological studies on acute hippocampal slices have elucidated much of what we know about this molecular cascade. Curiously, these slices require a period of "equilibration" for the recovery of electrophysiological properties such as LTP, implying ongoing time-dependent molecular events necessary for full expression of plasticity. Using standard immunofluorescence combined with confocal imaging and a novel data analysis approach, we implicate the transcription factor NF-кB in this plasticity-related molecular adaptation during equilibration. Marked differences in basal NF-кB activity in distinct cell types of the hippocampus were observed, with the amount of active NF-кB increasing throughout the 2-h equilibration period in all cell types. Moreover, distinct hippocampal neuronal subfields exhibit very different responses to the $\mathrm{GABA}_{\mathrm{A}}$ receptor blocker picrotoxin, the presence of which is required to achieve LTP in the dentate gyrus. These findings have implications for the use of acute hippocampal slices to study the effects of compounds that signal through NF-кB on synaptic plasticity. Further investigation into the cellular processes that occur during this molecular adaptation may increase our understanding of plasticity-related events common to both LTP and memory formation.
\end{abstract}

Synaptic plasticity and reorganization of neuronal connections within the hippocampus is observed following a learning event and is vital for the formation and consolidation of new memories (Morris et al. 2003; Lamprecht and LeDoux 2004). Such memoryassociated synaptic plasticity is underpinned by a molecular cascade driven by de novo gene transcription and protein synthesis (Stork and Welzl 1999; Igaz et al. 2002). Several transcription factors, most notably cAMP response element binding protein (CREB), have been implicated in this transcriptional cascade (Kandel 2001). Central to the elucidation of molecular mechanisms that mediate synaptic plasticity has been the electrophysiological study of long-term potentiation (LTP) and long-term depression (LTD), long-lasting enhancement and decrement in synaptic strength, respectively. LTP- and LTD-like phenomena are widely believed to underlie the initial cellular events that lead to memory consolidation (Bliss and Collingridge 1993).

In vitro electrophysiological research, such as that on LTP, makes use of acute hippocampal slice preparations that have been invaluable for furthering our knowledge of synaptic transmission within neuronal circuits of the hippocampus. The in vitro preparation, however, differs considerably in structural and molecular aspects from the hippocampal formation in vivo. An established step in most acute in vitro electrophysiological protocols is the requirement for a period of recovery or "equilibration" following slicing of the hippocampus. Although the length of time involved in this step can vary from 45 to $120 \mathrm{~min}$, and sometimes longer, this period is essential for the recovery of certain electrophysiological properties of the slice, in particular, the

\footnotetext{
${ }^{3}$ Corresponding author.
}

E-mail Keith.Murphy@ucd.ie; fax +353-01-7166920.

Article is online at http://www.learnmem.org/cgi/doi/10.1101//m.590007. ability to induce and maintain LTP. The need for such an equilibration period clearly implies the occurrence of key molecular events necessary for full expression of synaptic plasticity. In support of this, the period sees alterations in the phosphorylation status of a number of key proteins involved in LTP and LTD, for example, AMPA receptor subunits and various kinases (Taubenfeld et al. 2002; Oanh et al. 2004). By understanding how these changes contribute to the recovery of synaptic plasticity in hippocampal slice neuronal circuitry, we may gain a greater understanding of the underlying mechanisms of plasticity. In particular, equilibration period-related alterations at the level of transcription factor activity remain poorly understood (Danzer et al. 2004). In the present study we have focused on a key transcription factor implicated in plasticity, nuclear factor kappa B (NFкB) (Romano et al. 2006).

$\mathrm{NF}-\kappa \mathrm{B}$ is a dimeric protein made up of two subunits selected from a family of five (p50, p52, p65, c-Rel, and RelB), with the p50/p65 heterodimer by far the most abundant form. In neurons, NF- $\kappa$ B exists in two pools, a latent pool, sequestered inactive in the cytoplasm bound to its inhibitory chaperone ІкB, and an active pool in the nucleus where it functions to regulate gene expression. In order for latent NF-кB to become activated, ІкB must first be phosphorylated, which causes its dissociation from NF- $\kappa \mathrm{B}$ and targets it for degradation by the ubiquitin $26 \mathrm{~S}$ proteosome system. Free from the inhibitory constraints of IкB, NF-кB translocates to the nucleus, where it functions in initiating the transcription of a whole host of genes, including IкB, thus providing an auto-regulatory loop (Kaltschmidt et al. 2005). Such activation of NF- $\mathrm{kB}$ is mediated by several stimuli including glutamate. Furthermore, recent studies have indicated the requirement of active NF-кB for LTP, LTD, and spatial memory (Kaltschmidt et al. 2006; Romano et al. 2006). Moreover, employ- 
ing the same antibody approach as adapted in the present studies, Freudenthal et al. (2004) demonstrated that NF-кB is upregulated in the hippocampus following both high-frequency and low-frequency stimulation in vivo. Along with the recent identification of p65-containing protein complexes in synaptic terminals and their activity-mediated retrograde transport to the cell body, these properties of NF-кB position this transcription factor ideally to translate synaptic activity into a transcriptional program driving subsequent plasticity (Kaltschmidt et al. 1993; Meberg et al. 1996; Mattson and Camandola 2001; Wellmann et al. 2001; Meffert et al. 2003).

Here, we have adapted the active p65-specific antibody approach used by Freudenthal et al. (2004) to allow the imaging of NF- $\kappa$ B activity in distinct neuronal subfields of the hippocampus in the acute slice. We focused on the three primary neuronal cell populations of the hippocampal excitatory loop, namely the dentate granule cells and the CA3 and CA1 pyramidal cells. These cell groups are connected in series with the granule cells receiving synaptic input from the cortex, via the perforant path, transmitting to the CA3 pyramidals via their mossy fiber axons. CA3 cells connect, in turn, with the CA1 pyramidal neurons via Schaffer collaterals, with the CA1 cells finally transmitting back to the cortex. There are well-established differences in the plasticity mechanisms mobilized in each cell type. For example, LTP in the cortical-dentate granule cell or CA3-CA1 synaptic connection is NMDA receptor-dependent, while dentate-CA3 connections achieve LTP in a manner that is independent of NMDA receptor activity (Malenka and Bear 2004). Here, marked differences in basal NF- $\kappa$ B activity in distinct neuronal cell types of the hippocampus were observed. Moreover, not only does the amount of active NF-кB increase gradually throughout a 120 -min "equilibration" period in all cell types, but distinct hippocampal neuronal subfields exhibit very different responses to picrotoxin, the $\mathrm{GABA}_{\mathrm{A}}$ receptor blocker routinely used as an experimental tool in electrophysiological investigations of LTP.

\section{Results}

\section{Distribution of active NF-кB in the rat hippocampus acute slice preparation}

In this study we focused on the three key neuronal cell fields of the hippocampal excitatory loop, namely the dentate granule cells and the CA3 and CA1 pyramidal cells. In each of these cell fields, we observed a high proportion of nuclei that exhibited substantial expression of active NF-кB (Fig. 1). In each NF-кBpositive nucleus, compactions of discrete high-intensity staining were evident (Fig. 1, inset). As observed in previous studies (Kaltschmidt et al. 2000), this staining pattern is consistent with $\mathrm{NF}-\kappa \mathrm{B}$ bound to chromatin structures and actively involved in gene transcription.

In terms of NF-кB activity, qualitative differences were evident between the hippocampal cell populations. In the dentate gyrus, there is an obvious distinction between the outer four-fifth of the stratum granulosum, the cells of which expressed relatively high nuclear NF-кB activity, and the inner one to two layers of cells that, in contrast, expressed much lower levels of the active form of this transcription factor (Fig. 1). Here, the nuclear expression of NF- $\mathrm{BB}$ related to the maturity of the cell, as the distinction between inner and outer cells corresponded with that seen with polysialylated neural cell adhesion molecule (NCAM PSA), a neuroplastic marker expressed on immature neurons still being incorporated into the memory circuitry (Regan 2004). Curiously, the distinction clearly visible between CA3 and CA1 pyramidal neurons in terms of NF- $\mathrm{B}$ activity corresponds directly to the termination point of NCAM PSA-expressing mossy fiber axons of these same inner granule cells.
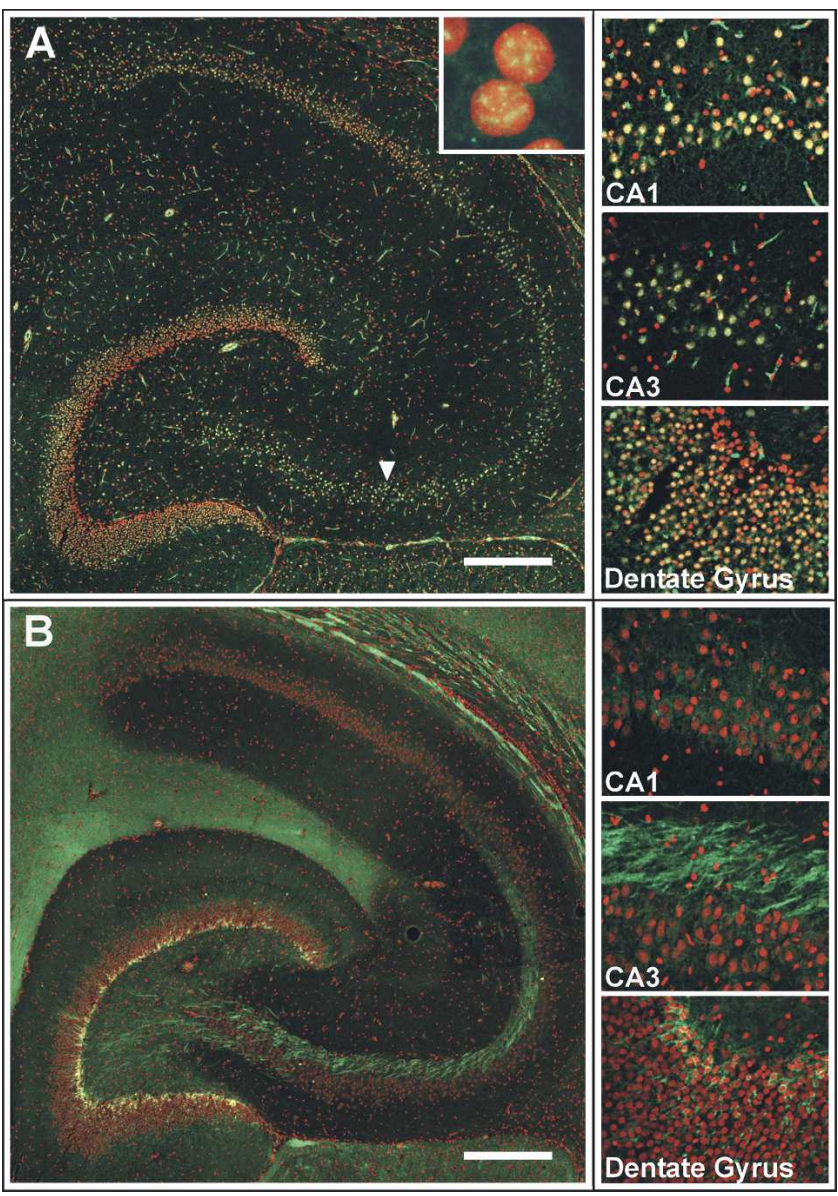

Figure 1. Hippocampal expression of active NF-кB and NCAM PSA in the post-natal day-30 rat. (A) A 12- $\mu$ m transverse section taken at -5.6 $\mathrm{mm}$ with respect to Bregma. Nuclei are stained with propidium iodide (PI, red), and active NF- $\mathrm{KB}$ was labeled using a FITC-conjugated secondary antibody (green). (Arrow) Position of nuclei within figure inset. (Inset) Punctate, high-intensity staining of activated NF-кB commonly seen distributed within many of the nuclei analyzed. (Right) Three highmagnification images represent the regions of the hippocampus containing the different cell subpopulations that were analyzed. $(B)$ The next serial section taken from the same brain as that in $A$. The nuclei were again stained using $\mathrm{PI}$ (red) and polysialylated neural cell adhesion molecule (NCAM PSA; green). (Right) The three high-magnification images represent the hippocampal regions analyzed throughout this study. Scale bars, $100 \mu \mathrm{m}$.

Within the CA3 pyramidal layer, an appreciable number of cell nuclei were also active-NF-кB-negative and were qualitatively different from the larger presumptive pyramidal neurons (Figs. 1, 2). Double-labeling studies confirmed a glial identity of the smaller, NF-кB-negative nuclei in CA3 stratum pyramidalis, as these clearly expressed the glial marker GFAP (Fig. 2). Of note, these astroglia do express active NF- $\kappa \mathrm{B}$ in the cytosolic domain of their processes and perinucleus (Fig. 2A,C, arrows).

Using confocal imaging and a customized analysis approach, the amount of active NF- $\mathrm{kB}$ in different cellular compartments, i.e., nucleus, perinucleus, and cytoplasm, within each distinct cell population of the hippocampus was quantified (Fig. 3). For this purpose, we treated the two distinct cell populations within the dentate granule cell layers separately. As judged by the relative intensity of immunofluorescence, the amount of active NF- $\mathrm{kB}$ in the cytoplasm was consistently lower than that measured in the nucleus for all cell types analyzed (Fig. 4). Furthermore, the level of active nuclear NF-кB was not uniform across 


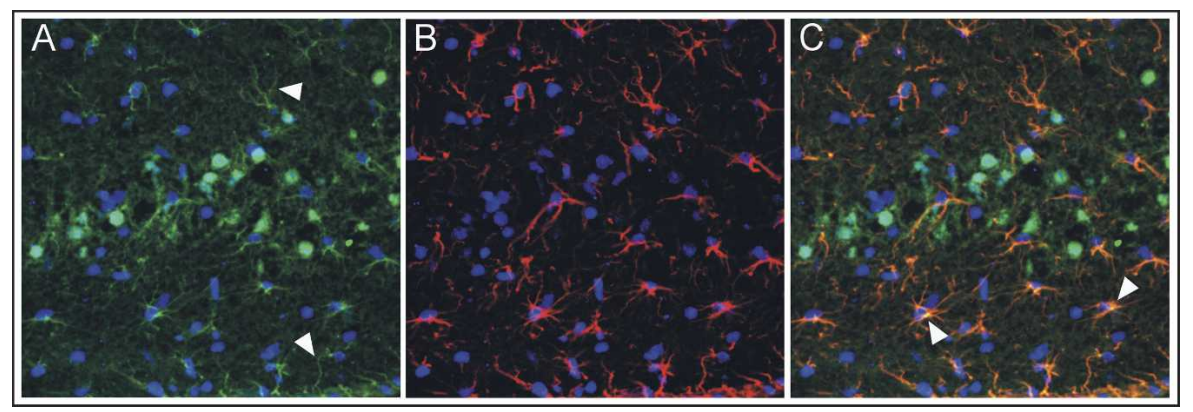

Figure 2. High-magnification image of the $C A 3$ region of the hippocampus taken from a post-natal day-30 male rat. The $12-\mu \mathrm{m}$ section was double-labeled for activated NF-кB (green) and glial fibrillary acidic protein (GFAP; red), and nuclei were counterstained using Hoechst dye (blue). (A) NF- $\mathrm{KB}$ and Hoechst staining. Notice the presence of NF-KB within GFAP-labeled astroglial processes (arrows). (B) GFAP and Hoechst staining. (C) The three channels combined show high amounts of active NF- $\mathrm{KB}$ colocalized with perinuclear GFAP staining (arrows).

the neuronal subpopulations of the hippocampus (Fig. 4). There were higher levels of NF- $\mathrm{KB}$ activity detected in the nuclei of the CA3 pyramidal cells relative to any other cell type. CA1 and granule cells in the outer portion of the stratum granulosum exhibited an intermediate activity level, with granule cells of the infragranular zone expressing relatively low levels of nuclear NF$\kappa \mathrm{B}$ activity (one-way ANOVA with Bonferroni post-hoc test, $P<0.0001)$.

\section{Comparison of NF-кB activity in the acute slice relative} to the in vivo situation

In order to relate the initial NF-кB activity levels reported above in the acute slice preparation to those found in vivo, equivalent transverse sections of the medial hippocampus $(-5.6 \mathrm{~mm}$ with respect to Bregma) were taken from naïve age-matched control animals sacrificed by decapitation; the whole brain was rapidly dissected and immediately snap frozen. Absolute nuclear and cytoplasmic levels of activated NF-кB were compared with the levels seen in vitro in slices frozen immediately post-cutting (Time 0 min). While cytoplasmic levels of activated NF-кB were lower in all cell populations analyzed from slices, only the granule cells of the outer dentate gyrus showed any difference in nuclear NF-кB activity (two-way ANOVA with Bonferroni post-hoc test, $P<0.0001$; Fig. 4).

\section{NF-кB activity increases over time in all cell subtypes in acute hippocampal slice preparations}

Active nuclear NF-кB increased over time in hippocampal slices in all cell subpopulations analyzed, with relative nuclear fluorescence intensities at 90 and 120 min significantly greater than initial (0 min) levels (Fig. 5). This rise in nuclear NF- $\kappa \mathrm{B}$ activity over time was reflected by similar increases in the perinuclear regions, suggesting a true activation/nuclear relocalization process (data not shown).

NF- $\kappa$ B activity appeared to follow distinct temporal profiles in different cell types. The CA3 pyramidal neurons exhibited a rise in NF-кB activity following $90 \mathrm{~min}$ of incubation that remained elevated at the 120-min time point (Fig. 5). The increase in NF- $\mathrm{BB}$ activity appeared earlier, after only $60 \mathrm{~min}$ of incubation, in the CA1 region and again remained elevated until 120 min. In all cases, the temporal profiles of perinuclear NF-кB activity closely matched those of the corresponding nuclear activities (data not shown).

Despite very different basal nuclear activity levels, the increase in NF-кB activity in the inner and outer cell layers of the dentate gyrus was similar over time. Nuclear NF-кB activity increased in neurons of the inner dentate after just $30 \mathrm{~min}$ and gradual increase in the amount of active nuclear NF-кB over the 120-min period of slice "equilibration." In order to demonstrate the transcriptional relevance of this rise in NF- $\mathrm{kB}$ activity, we measured the amount of the inhibitory protein $I \kappa B \alpha$ in the cytosolic fraction of these slices. As NF-кB activation leads to the increased transcription of $\mathrm{I} \kappa \mathrm{B} \alpha$, enhanced $\mathrm{NF}-\kappa \mathrm{B}$ activity should be reflected by an increase in I $\kappa \mathrm{B} \alpha$ expression. In addition, activation of NF- $\mathrm{kB}$ involves the phosphorylation of IкB $\alpha$; dissociation from NF-кB allows nuclear translocation with phosphoIкB $\alpha$ targeted for degradation by the ubiquitin $26 \mathrm{~S}$ proteosome system. Using Western immunoblot techniques with the cytosolic fraction of whole hippocampal slices, we found that the amount of IкB $\alpha$ protein increased by $30 \%$ in slices that had been equilibrated for 120 min compared with slices analyzed immediately after cutting. Moreover, the phosphorylated form of IкB $\alpha$ increased by $90 \%$ over the same time period (unpaired Student's $t$-test, $P<0.05$; Fig. 6).

\section{Picrotoxin differentially affects NF-кB activity in distinct neuronal subtypes}

In a final experiment, we investigated the effect of $\mathrm{GABA}_{\mathrm{A}}$ receptor blockade with picrotoxin on NF- $\mathrm{B}$ activity throughout the slice. Picrotoxin (100 $\mu \mathrm{M}$ for $30 \mathrm{~min})$ had no effect on NF-кB activity in CA1 pyramidal neurons (Fig. 7). In contrast, picrotoxin caused a robust increase in nuclear NF- $\mathrm{B}$ activity in CA3 pyramidal neurons (unpaired Student's $t$-test, $P<0.05$; Fig. 7) and immature granule cells of the dentate gyrus (unpaired Student's $t$-test, $P<0.001$; Fig. 7). Interestingly, picrotoxin exerted an opposite effect on NF- $\mathrm{B}$ activity in mature cells of the outer dentate stratum granulosum, causing a decrease in nuclear activity (unpaired Student's $t$-test, $P<0.05$; Fig. 7).

\section{Discussion}

Hippocampal synaptic plasticity, required for the effective storage of memory, is driven by a cascade of transcription and new protein synthesis (Bourtchouladze et al. 1998; Lamprecht and LeDoux 2004; Regan 2004). Recent studies have implicated the transcription factor NF-кB in hippocampal LTP, LTD, and spatial memory (Freudenthal et al. 2004; Kaltschmidt et al. 2006; O'Mahony et al. 2006; Romano et al. 2006; Vernon et al. 2006). Thus, differential basal activities of this cardinal transcription factor in distinct neuronal subpopulations of the hippocampus have important implications for the nature of plasticity mobilized in each area. Indeed, the expression of active NF-кB does seem to relate to plasticity, at least as it is measured by electrophysiological methods such as LTP. Specifically, while neuronal cells of the CA1, CA3, and dentate gyrus all support NMDA receptor-dependent LTP, the mossy fiber synapses onto CA3 pyra- 

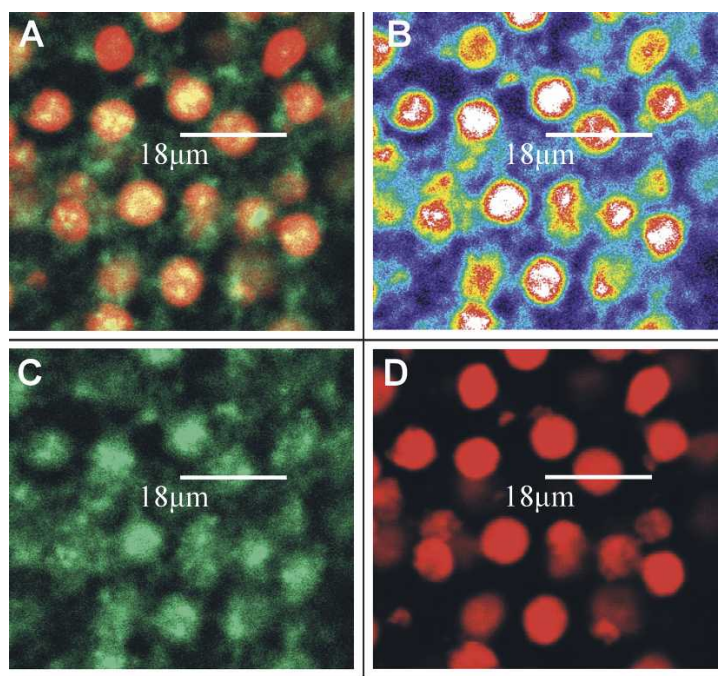

E

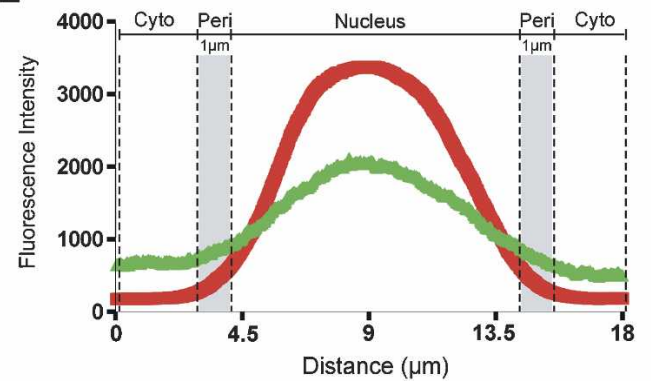

Figure 3. Method used to analyze the NF- $\mathrm{kB}$ activation (fluorescence intensity of FITC) in the nuclear and cytoplasmic regions of individual hippocampal cells. $(A-D)$ An area of the outer dentate gyrus captured using a $40 \times 10.8 \mathrm{~W}$ water-dipping lens on a confocal microscope (Zeiss, LSM Pascal). (A) NF-kB-labeled hippocampal nuclei. (B) The same cells as those in $A$, but with a rainbow palette used to emphasize the regions of highest NF-кB activity more clearly; the hotter the color, the greater the level of active NF-кB. (C) The same cells as in $A$ minus the red channel, i.e., only the green channel highlighting NF-KB staining is present. (D) The same cells as in $A$ minus the green channel, i.e., only the red channel corresponding to propidium iodide ( $\mathrm{Pl}$ )-labeled nuclei are represented. An 18- $\mu \mathrm{m}$ line was drawn across each nucleus to be analyzed, and the fluorescence intensities for PI and FITC were separated out (E). From the raw fluorescence intensity values at each data point along the line, average nuclear, perinuclear, and cytoplasmic levels of NF-кB were calculated. Twenty percent of the maximum PI value of the cell was set as the nuclear boundary. Perinuclear values were taken to be all those values a distance of $1 \mu \mathrm{m}$ from the nuclear boundary. Cytoplasmic values were taken to be all those values outside the perinuclear boundary.

midal dendrites express NMDA receptor-independent LTP. The substantially higher levels of NF-кB activity in CA3 pyramidals may represent a fundamental property of these cells, providing them with a set point closer to a threshold transcriptional activity that facilitates NMDA receptor-independent plasticity mechanisms.

There is also a marked distinction in nuclear NF-кB activity between the mature dentate granule neurons and the immature, highly neuroplastic cells of the infragranular zone. In this regard, it is of interest to note that NCAM-mediated adhesion upregulates NF- $\mathrm{KB}$ activity through kinase cascades similar to those employed by cytokines (Choi et al. 2001). Such NCAM-mediated adhesion, a feature of mature synaptic connections, may contribute to a build-up of NF- $\mathrm{B}$ activity in the nuclei of the mature hippocampal neuronal populations. Conversely, the immature nature of the infragranular cells along with the presence of high levels of PSA, a post-translational modification of NCAM that destabilizes NCAM-mediated adhesion, likely contributes to the lack of basal nuclear NF- $\kappa \mathrm{B}$ activity in these cells.

Of particular interest for the current study is the need for a period of recovery or "equilibration" following slicing of the hippocampus. This period is essential for the recovery of certain electrophysiological properties of the slice, in particular, the ability to induce and maintain LTP. Using electron microscopy, Kirov et al. $(1999,2004)$ observed the appearance of 40\%-90\% additional synapses in hippocampal slices (depending on the age of the animal) compared with perfusion-fixed tissue during the first $2 \mathrm{~h}$ of this recovery period. Our results implicate NF-кB in these processes. NF-кB activity rises in acute hippocampal slices over the 120-min incubation period following slicing in a standard aCSF solution at $32^{\circ} \mathrm{C}$ in all cell populations studied. Accompanying this rise in nuclear NF-кB are 30\% and 90\% increases in total and phosphorylated $І \kappa B \alpha$, respectively. The former observation suggests NF-kB-driven transcription to have increased, as sustained activation of NF- $\mathrm{B}$ results in the resynthesis of IкB $\alpha$ through NF-кB-mediated gene expression (Chiao et al. 1994), while the latter supports an activation of NF-кB through the conventional signaling cascade. NF-кB has been shown to be up-regulated in times of cellular stress and can act either as a pro- or anti-apoptotic agent, depending on the stimulus (Lin et al. 1999; Kaltschmidt et al. 2000). Specifically, several mechanisms might explain the activation and nuclear translocation of NF-кB in the slice setting. First, studies have shown that

\section{A}

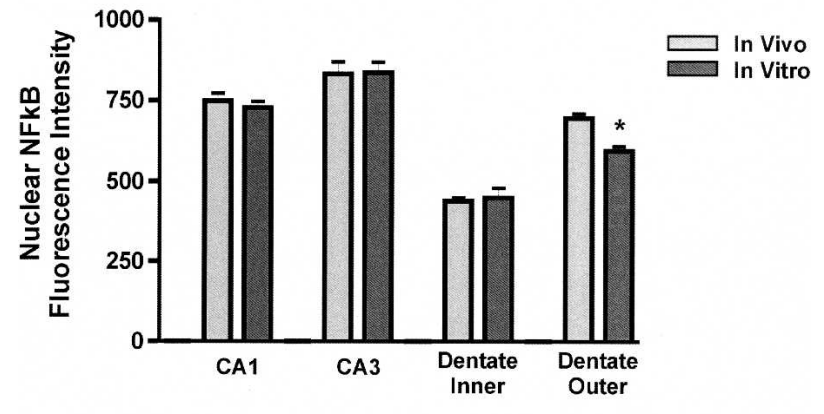

B

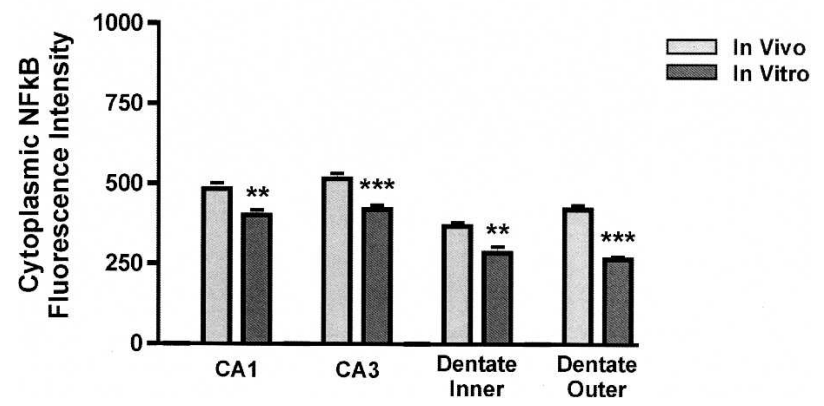

Figure 4. Comparison of nuclear and cytoplasmic NF- $\mathrm{kB}$ activity in acute hippocampal slices (in vitro) frozen immediately post-dissection (i.e., Time $0 \mathrm{~min}$ ) relative to NF- $\mathrm{KB}$ activity levels in the in vivo situation. Nuclear $(A)$ and cytoplasmic $(B)$ NF-KB activity levels are reported in each neuronal subtype. Data are mean \pm SEM absolute fluorescence intensity. Values significantly different from in vivo control (one-way ANOVA with Bonferroni post-hoc test; $P<0.0001)$ are indicated by an asterisk: $\left(^{*}\right) P$-value $<0.05,\left({ }^{* *}\right) P$-value $\left.<0.01,{ }^{* * *}\right) P$-value $<0.001$. (CA1) CA1 pyramidal cells, (CA3) CA3 pyramidal cells. 


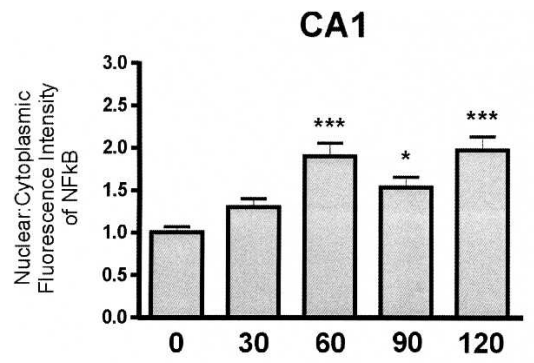

\section{Inner Dentate}

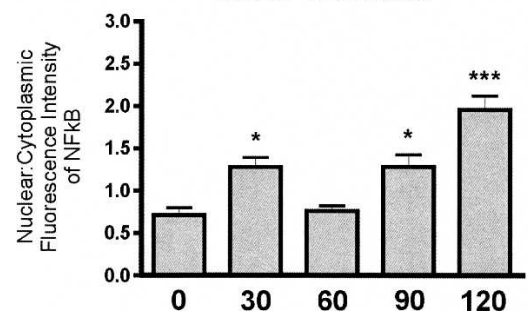

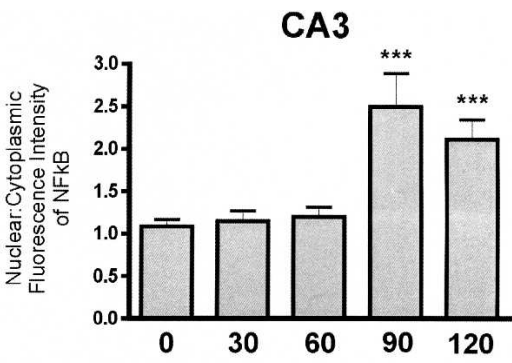

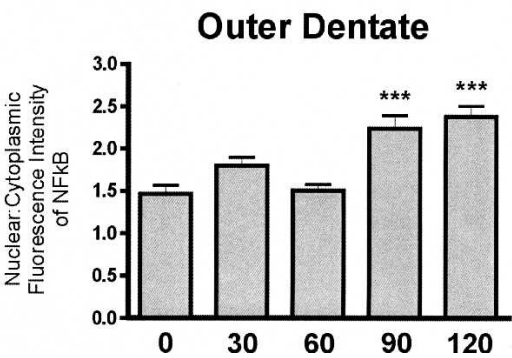

Figure 5. Influence of time and cell-type on NF-kB activity in the hippocampal slice preparation. Data are mean \pm SEM relative nuclear:cytoplasmic NF- $\mathrm{B}$ fluorescence intensity. Values significantly different from Time 0 -min slice (one-way ANOVA; $P<0.001$ ) are indicated by an asterisk: $\left(^{*}\right) P$ value $<0.05,\left({ }^{* *}\right) P$-value $<0.001$. (CA1) CA1 pyramidal cells, (CA3) CA3 pyramidal cells.

the ATP levels in slices plummet on transfer to warm buffer, requiring $45 \mathrm{~min}$ to return to normal (Whittingham et al. 1984; Aitken et al. 1995). Critically, during this period, slices are essentially experiencing in vitro ischemia. NF- $\mathrm{kB}$ has been shown to be up-regulated in response to products of ischemia such as $\mathrm{H}_{2} \mathrm{O}_{2}{ }^{-}$(Schreck et al. 1991; Rosenberger et al. 2001; Shen et al. 2003). Secondly, hippocampal slices may undergo NMDAmediated excitotoxicity immediately post-cutting (Feig and Lipton 1990), triggering an NF-кB-dependent anti-apoptotic cascade (Hardingham and Bading 2003). Third, the mechanical trauma caused by simply cutting slices may release pro-inflammatory cytokines resulting in receptor-mediated activation of NF-кB. For example, Schneider et al. (1998) showed an immediate and enduring $(+5 \mathrm{~h})$ increase in IL-1 $\beta$ mRNA in acute slice preparations. In particular, such a role for IL- $1 \beta$ and TNF $\alpha$ is supported by preliminary data from our group that demonstrates equivalent increases in nuclear NF-кB activity following exposure of slices to these pro-inflammatory cytokines (Sheridan et al. 2006; G.K. Sheridan, M. Pickering, P.N. Moynagh, J.J. O'Connor, and K.J. Murphy, unpubl.).

In vivo studies have clearly indicated activation of NF-кB accompanies LTP, LTD, and learning in the hippocampus in the absence of the confounding issues encountered in the acute slice preparation (Freudenthal et al. 2004; Kaltschmidt et al. 2006; Romano et al. 2006). In particular, Freudenthal et al. (2004), using precisely the same antibody marker, demonstrated increased activity of NF-кB following both high- and low-frequency stimulation of the perforant path in vivo. Whatever the signaling mechanism in the slice, the equilibration phase sees the activation of this cardinal transcription factor critical for synaptic plasticity. It is likely that the resultant gene regulation serves to set up the hippocampal slice circuitry at a molecular level in support of in vitro plasticity.

We also tested the possible contribution of picrotoxin, a $\mathrm{GABA}_{\mathrm{A}}$ receptor antagonist, to NF-кB-mediated transcriptional events that might underpin synaptic plasticity. Picrotoxin is of particular importance in the dentate as LTP generation in that
$2 \mathrm{Cl}^{-}$co-transporters (Plotkin et al. 1997; Ge et al. 2006). Since GABA is excitatory in neural cells of the inner dentate and inhibitory in mature granule neurons of the outer dentate, it is perhaps not surprising that picrotoxin has opposing actions in these neuronal subpopulations.

These studies reveal substantial alterations in NF-кBmediated transcription during the "equilibration" period in in vitro hippocampal slices. These changes are time-, cell type-, and $\mathrm{GABA}_{\mathrm{A}}$ receptor blockade-dependent. Thus, these variables will significantly impact the outcome of studies on hippocampal synaptic plasticity and, in particular, the effects of interventions that signal through NF- $\mathrm{B}$, such as cytokines. Differences in the methods of slice preparation and "equilibration" conditions between laboratories may represent a major contributory factor to the plethora of discordant findings in this field of research. Further study into the cellular processes occurring during slice "equilibration" may shed light on plasticity-related events necessary for the expression of LTP and memory formation in the hippocampus.

\section{Materials and Methods}

\section{Hippocampal slice preparation}

Post-natal day 28-32 male Wistar rats (50-75 g) were used throughout this study and were obtained from the Biomedical Facility, University College Dublin, Ireland. All experimental procedures were approved by the Animal Research Ethics Committee of the Biomedical Facility at University College Dublin, and were carried out by individuals who held the appropriate license issued by the Minister for Health and Children. Animals were anesthetized using isoflurane (Abbott Laboratories Ireland Ltd.) and decapitated by guillotine. The brain was rapidly dissected out and placed into ice-cold artificial cerebro-spinal fluid (aCSF) bubbled with $95 \% \mathrm{O}_{2}$ and $5 \% \mathrm{CO}_{2}$ (aCSF composition: $120 \mathrm{mM} \mathrm{NaCl}, 26 \mathrm{mM} \mathrm{NaHCO}, 1.25 \mathrm{mM} \mathrm{NaH}_{2} \mathrm{PO}_{4}, 2.5 \mathrm{mM}$ $\mathrm{KCl}, 2 \mathrm{mM} \mathrm{MgSO}{ }_{4} \cdot 7 \mathrm{H}_{2} 0,2 \mathrm{mM} \mathrm{CaCl}$, and $10 \mathrm{mM}$ D-Glucose). Transverse hippocampal slices $(400-\mu \mathrm{m})$ were cut from both 
A

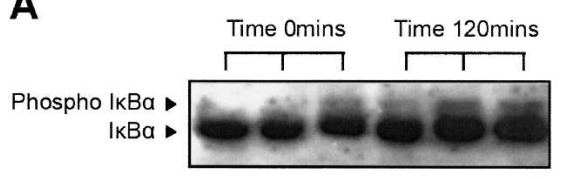

B
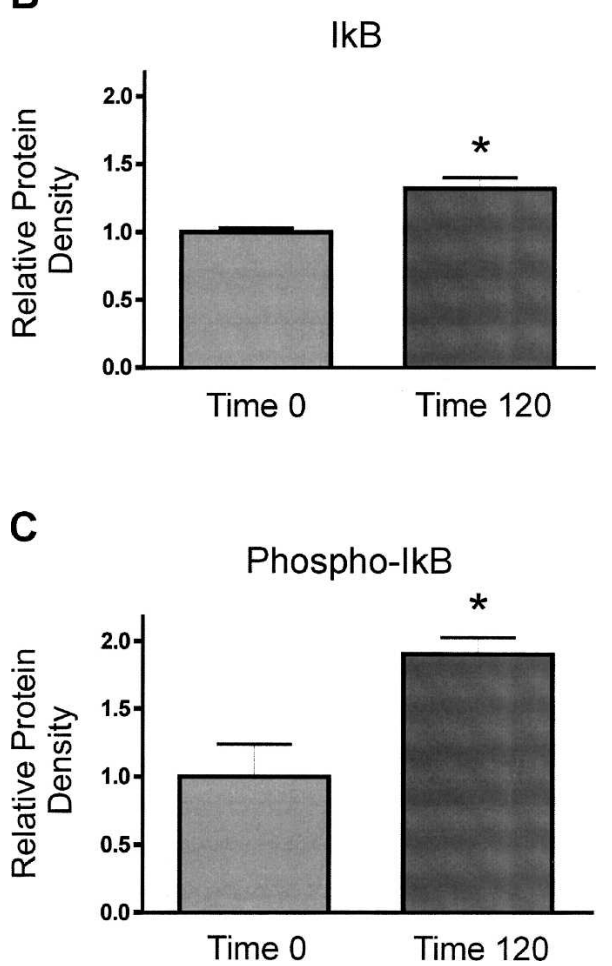

Figure 6. Influence of time on the protein level and phosphorylation status of $I_{\kappa} B \alpha$ in the hippocampal slice preparation. (A) Representative Western blot of the cytoplasmic protein fractions from whole hippocampal slices that were homogenized either immediately after being cut with the vibroslice (Time $0 \mathrm{~min}$ ), or were homogenized following $120 \mathrm{~min}$ of incubation in a standard aCSF solution at $32^{\circ} \mathrm{C}$ (Time $120 \mathrm{~min}$ ). Each lane is a pool of tissue from five 400- $\mu$ m slices. (B) Densitometric analysis of the $I_{\kappa} B \alpha$ protein band. Data are mean \pm SEM $I_{\kappa} B \alpha$ protein expression relative to mean value at Time 0 min. (C) Levels of the phosphorylated form of $I_{\kappa} B \alpha$. Data are mean \pm SEM phospho-IкB $\alpha$ expression relative to mean value at Time $0 \mathrm{~min}$. Values significantly different from Time $0 \mathrm{~min}$ (unpaired Student's $t$-test, $P<0.05$ ) are indicated by an asterisk: $\left(^{*}\right) P$ value $<0.05$.

hemispheres using a vibroslice (Campden Instruments). Slices corresponding to 0-min incubation time were immediately snapfrozen following cutting. Subsequent hippocampal slices were transferred to a submerged incubation chamber containing bubbled aCSF at $32^{\circ} \mathrm{C}$. They remained untreated and were allowed to incubate for varying lengths of time post-cutting (i.e., $30,60,90$, and $120 \mathrm{~min}$ ) before being snap frozen. This procedure was carried out on three animals.

Hippocampal slices from another three rats were prepared in the same fashion as just outlined. Three slices were left untreated for $90 \mathrm{~min}$, at which point $100 \mu \mathrm{M}$ picrotoxin was added to the bath. These slices were allowed to incubate in this solution of picrotoxin and aCSF for a further 30 min before being snap frozen. Time-matched controls were allowed to incubate untreated for $120 \mathrm{~min}$.

Slices were covered in OCT (optimal cutting temperature compound, Agar UK) and snap frozen in n-hexane that had been cooled to $-80^{\circ} \mathrm{C}$ with compressed $\mathrm{CO}_{2}$.

\section{Cryosectioning and immunofluorescence of hippocampal slices}

The frozen hippocampal slices were cryosectioned into 12- $\mu \mathrm{m}$ thick sections that were adhered to glass slides coated with polyL-lysine. Sections were permeablized using a solution of $0.1 \%$ Triton X in phosphate buffered saline (PBS) for $30 \mathrm{~min}$. Following this, sections were fixed in $70 \%$ ethanol for $30 \mathrm{~min}$. The sections were then incubated overnight $(18 \mathrm{~h})$ with the primary antibody MAB3026 (Chemicon), which binds to an epitope overlapping the nuclear location signal on the p65 subunit of the NF-кB heterodimer. Thus, it selectively binds to the activated form of NF$\kappa B$. Following two 10-min washes in PBS, sections were incubated for $3 \mathrm{~h}$ with an anti-mouse IgG secondary antibody labeled with the fluorescent marker FITC. The secondary antibody was then washed off and sections were dipped in propidium iodide (PI) for $5 \mathrm{sec}$ in order to stain the nuclei red. A drop of Citifluor Glycerol PBS solution (Agar Scientific) was used to mount each section with a coverslip, and the slides were stored in darkness at $4^{\circ} \mathrm{C}$.

\section{Polysialylated neural cell adhesion molecule (NCAM PSA) immunofluorescence}

In order to demonstrate the clear difference in the plastic potential of cells of the inner and outer dentate gyrus, immunofluorescent labeling of polysialylated neural cell adhesion molecule (NCAM PSA)-positive cells of the hippocampus was also carried out. Twelve-micrometer transverse sections from the medial hippocampus ( $-5.6 \mathrm{~mm}$ with respect to Bregma) (Paxinos and Watson 2005) were taken from a naïve post-natal day-30 rat whose brain had been immediately fresh frozen in OCT following decapitation. Alternating sections were also stained for active NF-кB as described above (see Fig. 1). Sections that were to be stained for NCAM PSA were transferred directly to a solution of 70\% ethanol and fixed for $30 \mathrm{~min}$. The staining protocol for NCAM PSA followed the same steps as described for the NF-кB-labeling procedure. The primary antibody used was anti-PSA (generous gift of Prof. G. Rougon; Rougon et al. 1986), a mouse IgM monoclonal antibody. An anti-mouse IgM secondary antibody conjugated with FITC was used to detect NCAM PSA staining.

\section{GFAP and NF-кB immunofluorescence}

In order to highlight the differences in the levels of activated NF- $\kappa \mathrm{B}$ between CA3 pyramidal neurons and astroglial cells within this region of the hippocampus, double-labeling of glial fibrillary acidic protein (GFAP) and NF- $\mathrm{B}$ was carried out. Twelve-micrometer transverse sections from the medial hippocampus $(-5.6 \mathrm{~mm}$ with respect to Bregma) were taken from a naïve post-natal day-30 rat. Sections were double-labeled using the same anti-NF- $\mathrm{KB}$ antibody as above and also a rabbit IgG monoclonal anti-GFAP primary antibody (Sigma-Aldrich). An anti-mouse FITC-conjugated secondary antibody was used to bind to the NF-кB antibody, while an anti-mouse TRITCconjugated secondary antibody was used to label GFAP. Nuclei were counterstained using Hoechst 33258 (Molecular Probes).

\section{Confocal microscopy}

Confocal images were taken using a $40 \times / 0.8 \mathrm{~W}$ water-dipping lens (Zeiss Achroplan). Images were captured from three distinct regions of the hippocampus, i.e., CA1, CA3, and the apex of the dentate gyrus. The specific areas imaged were kept consistent between sections (see Fig. 1). Three sections from each of three rats were used for analysis. Each image was captured twice in a time-series scan $30 \mathrm{sec}$ apart, and the fluorescence intensities of both scans were averaged.

\section{Analysis of confocal images}

Approximately 12-15 nuclei per image were randomly selected for analysis. Using the confocal software package LSM Pascal, an 18 - $\mu \mathrm{m}$ line was drawn across each nucleus (see Fig. 3). The length of the line was kept consistent in order to automate the data analysis. Fluorescence intensities for NF- $\mathrm{KB}$ and PI staining were 
CA1

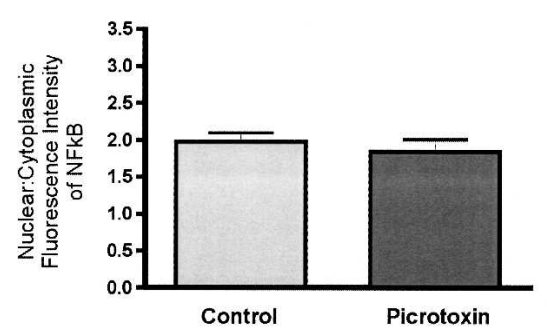

Inner Dentate

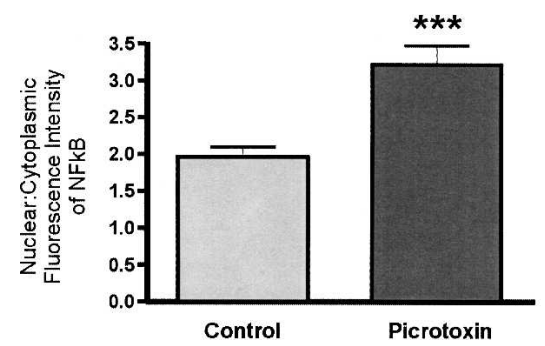

CA3

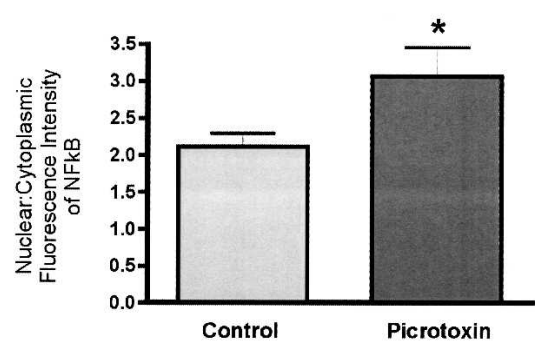

Outer Dentate

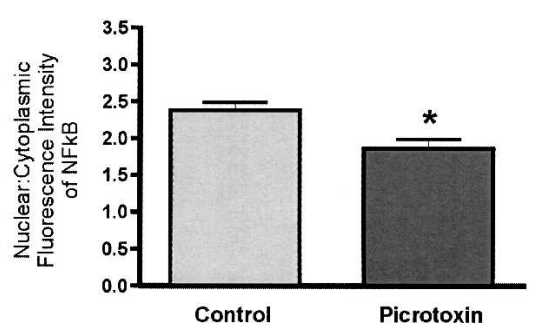

Figure 7. Influence of the $\mathrm{GABA}_{\mathrm{A}}$ receptor antagonist, picrotoxin $(30 \mathrm{~min} ; 100 \mu \mathrm{M})$ on $\mathrm{NF}-\kappa \mathrm{B}$ activity in the hippocampal slice preparation. Data are mean \pm SEM relative nuclear:cytoplasmic NF- $\kappa B$ fluorescence intensity. Values significantly different from aCSF control (unpaired Student's $t$-test) are indicated by an asterisk: $\left(^{*}\right) P$-value $<0.05,\left(^{* * *}\right) P$-value $<0.001$. (CA1) CA1 pyramidal cells, (CA3) CA3 pyramidal cells.

obtained at each data point along the length of the line. In this manner, nuclear NF-кB fluorescence intensities were measured as well as the intensity of staining at a certain distance from the nucleus. Taking Figure 3 as a typical example, we defined the nuclear boundaries as $20 \%$ of the maximum PI fluorescence intensity value for each and every individual cell analyzed. The perinuclear region was taken to be that area falling $1 \mu \mathrm{m}$ on either side of the nuclear boundaries. Similarly, the cytoplasmic regions were defined as the areas lying outside the perinuclear boundaries.

Because of the very noticeable difference between the intensity of nuclear NF-кB staining in the inner cell layer of the dentate gyrus (i.e., one to two cell layers thick) compared with the rest of the dentate (i.e., outer layers), we decided to analyze these cells as distinct and separate regions. Therefore, we analyzed four distinct cell subpopulations of the hippocampus, i.e., CA1, CA3, and the inner and outer dentate gyrus. For each region we calculated the ratio of nuclear to cytoplasmic NF- $\kappa$ B activity. This was achieved by calculating the average nuclear and average cytoplasmic fluorescence intensities for each cell. The ratio was then calculated according to the formula:

$$
\frac{\mathrm{Fn}-\mathrm{Fc}}{\mathrm{FC}} \text {, }
$$

where $\mathrm{Fn}=$ average nuclear fluorescence intensity, and $\mathrm{Fc}=$ average cytoplasmic fluorescence intensity.

All results represent the mean values \pm SEM. One-way ANOVAs were performed to compare differences between timepoints, and unpaired Student's $t$-tests were used to compare differences between control and picrotoxin-treated hippocampal slices.

\section{Cytosolic protein fractionation for Western blotting}

Three post-natal day 28-32 male Wistar rats (50-75 g) were sacrificed as above. Five 400- $\mu \mathrm{m}$ transverse hippocampal slices were

was conducted using the BCA Protein Assay Kit protocol (Pierce). Standard curves of known protein concentration were constructed using BSA as a standard. All protein samples were standardized to $1 \mu \mathrm{g} / \mathrm{mL}$. Reducing SDS-PAGE sample buffer $(3 \times$ Blue loading buffer $+10 \%[\mathrm{v} / \mathrm{v}]$ dithiothreitol [DTT]) was added to the protein samples. Samples were boiled for $10 \mathrm{~min}$ at $100^{\circ} \mathrm{C}$ to denature the proteins.

\section{Western blotting}

Protein samples were separated on a 10\% SDS-PAGE separating gel and 5\% stacking gel using a minigel apparatus $(10 \mathrm{~cm} \times 15$ $\mathrm{cm} \times 1.5 \mathrm{~mm}$, Bio-Rad). Eighteen microliters of sample was added to each well, and the gel was run at $200 \mathrm{~V}$. Densitometry was performed on a Coomassie Brilliant Blue-stained gel $(0.25 \%$ $[\mathrm{w} / \mathrm{v}]$ brilliant blue diluted in Destain [40\% (v/v) methanol, 10\% (v/v) acetic acid]) using the software Scion Image and Gel Plot2 Macros. The volume of sample protein loaded was adjusted accordingly to ensure equal protein loading. The gel was run again with the adjusted sample volumes and transferred onto a nitrocellulose membrane. Ponceau S staining was also carried out to again ensure equal protein loading in the gel.

The nitrocellulose membrane was incubated for $1 \mathrm{~h}$ in blocking buffer (1\% Marvel in TBS-T at $\mathrm{pH} 7.4$ ). The nitrocellulose was then incubated overnight at $4^{\circ} \mathrm{C}$ with the primary antibody (1:5000 dilution), which was a rabbit affinity-purified polyclonal antibody targeted against a peptide on the $\mathrm{N}$ terminus of I $\mathrm{B} \alpha$ (C-15, Santa Cruz Biotechnology). Excess primary antibody was then washed off, and the nitrocellulose membrane was incubated for $1 \mathrm{~h}$ at room temperature in a 1:4000 dilution of an anti-rabbit polyclonal antibody conjugated to horseradish peroxidase (HRP) label. Western blots were developed using WestDura (Pierce) developer. Densitometry was performed on the blots using Scion Image software. Results represent the mean \pm SEM values, and unpaired Student's $t$-tests were used to compare differences between Time $0 \mathrm{~min}$ and Time $120 \mathrm{~min}$ slices. 


\section{Acknowledgments}

This work was supported by Science Foundation Ireland.

\section{References}

Aitken, P.G., Breese, G.R., Dudek, F.F., Edwards, F., Espanol, M.T., Larkman, P.M., Lipton, P., Newman, G.C., Nowak, T.S., Panizzon Jr., K.L., et al. 1995. Preparative methods for brain slices: A discussion. J. Neurosci. Methods 59: 139-149.

Bliss, T.V.P. and Collingridge, G.L. 1993. A synaptic model of memory: Long term potentiation and the hippocampus. Nature 361: 31-39.

Bourtchouladze, R., Abel, T., Berman, N., Gordon, R., Lapidus, K., and Kandel, E.R. 1998. Different training procedures recruit either one or two critical periods for contextual memory consolidation, each of which requires protein synthesis and PKA. Learn. Mem. 5: 365-374.

Chiao, P.J., Miamoto, S., and Verma, I.M. 1994. Autoregulation of IkB $\alpha$ activity. Proc. Natl. Acad. Sci. 91: 28-32.

Choi, J., Krushel, L.A., and Crossin, K.L. 2001. NF-кB activation by $\mathrm{N}-\mathrm{CAM}$ and cytokines in astrocytes is regulated by multiple protein kinases and redox modulation. Glia 33: 45-56.

Danzer, S.C., Pan, E., Nef, S., Parada, L.F., and McNamara, J.O. 2004. Altered regulation of brain-derived neurotrophic factor protein in hippocampus following slice preparation. Neuroscience 126: 859-869.

Feig, S. and Lipton, P. 1990. N-methyl-D-aspartate receptor activation and $\mathrm{Ca}^{2+}$ account for poor pyramidal cell structure in hippocampal slices. J. Neurochem. 55: 473-483.

Freudenthal, R., Romano, A., and Routtenberg, A. 2004. Transcription factor NF-кB activation after in vivo perforant path LTP in mouse hippocampus. Hippocampus 14: 677-683.

Ge, S., Goh, E.L.K., Sailor, K.A., Kitabatake, Y., Ming, G.-L., and Song, H. 2006. GABA regulates synaptic integration of newly generated neurons in the adult brain. Nature 439: 589-593.

Hardingham, G.E. and Bading, H. 2003. The Yin and Yang of NMDA receptor signalling. Trends Neurosci. 26: 81-89.

Igaz, L.M., Vianna, M.R.M., Medina, J.H., and Izquierdo, I. 2002. Two time periods of hippocampal mRNA synthesis are required for memory consolidation of fear-motivated learning. J. Neurosci. 22: 6781-6789.

Kaltschmidt, C., Kaltschmidt, B., and Baeuerle, P.A. 1993. Brain synapses contain inducible forms of the transcription factor NF-кB. Mech. Dev. 43: $135-147$.

Kaltschmidt, B., Kaltschmidt, C., Hofmann, T.G., Hehner, S.P., Droge, W., and Schmitz, M.L. 2000. The pro- or anti-apoptotic function of NF-кB is determined by the nature of the apoptotic stimulus. Eur. J. Biochem. 267: 3828-3835.

Kaltschmidt, B., Widera, D., and Kaltschmidt, C. 2005. Signaling via NF-кB in the nervous system. Biochim. Biophys. Acta 1745: 287-299.

Kaltschmidt, B., Ndiaye, D., Korte, M., Pothion, S., Arbibe, L., Prüllage, M., Pfeiffer, J., Lindecke, A., Staiger, V., Israël, A., et al. 2006. NF-кB regulates spatial memory formation and synaptic plasticity through protein kinase A/CREB signaling. Mol. Cell. Biol. 26: 2936-2946.

Kandel, E.R. 2001. The molecular biology of memory storage: A dialogue between genes and synapses. Science 294: 1030-1038.

Kirov, S.A., Sorra, K.E., and Harris, K.M. 1999. Slices have more synapses than perfusion-fixed hippocampus from both young and mature rats. J. Neurosci. 19: 2876-2886.

Kirov, S.A., Petrak, L.J., Fiala, J.C., and Harris, K.M. 2004. Dendritic spines disappear with chilling but proliferate excessively upon rewarming of mature hippocampus. Neuroscience 127: 69-80.

Lamprecht, R. and LeDoux, J. 2004. Structural plasticity and memory. Nat. Rev. Neurosci. 5: 45-54.

Lin, B., Williams-Skipp, C., Tao, Y., Schleicher, M.S., Cano, L.L., Duke, R.C., and Scheinman, R.I. 1999. NF-кB functions as both a pro-apoptotic and anti-apoptotic regulatory factor within a single cell type. Cell Death Differ. 6: 570-582.

Liu, Y.B., Lio, P.A., Pasternak, J.F., and Trommer, B.L. 1996. Developmental changes in membrane properties and postsynaptic currents of granule cells in rat dentate gyrus. J. Neurophysiol. 76: $1074-1088$.

Malenka, R.C. and Bear, M.F. 2004. LTP and LTD: An embarrassment of riches. Neuron 44: 5-21.

Mattson, M.P. and Camandola, S. 2001. NF-кB in neuronal plasticity and neurodegenerative disorders. J. Clin. Invest. 107: 247-254.

Meberg, P.J., Kinney, W.R., Valcourt, E.G., and Routtenberg, A. 1996. Gene expression of the transcription factor NF-кB in hippocampus: Regulation by synaptic activity. Brain Res. Mol. Brain Res. 38: $179-190$.

Meffert, M.K., Chang, J.M., Wiltgen, B.J., Fanselow, M.S., and Baltimore, D. 2003. NF-кB functions in synaptic signaling and behavior. Nat. Neurosci. 6: 1072-1078.

Morris, R.G.M., Moser, E.I., Riedel, G., Martin, S.J., Sandin, J., Day, M., and O'Carroll, C. 2003. Elements of a neurobiological theory of the hippocampus: The role of activity-dependent synaptic plasticity in memory. Philos. Trans. R. Soc. Lond. B Biol. Sci. 358: 773-786.

Oanh, H.H., Delgado, J.Y., and O'Dell, T.J. 2004. Phosphorylation of proteins involved in activity-dependent forms of synaptic plasticity is altered in hippocampal slices maintained in vitro. J. Neurochem. 91: $1344-1357$.

O’Mahony, A., Raber, J., Montano, M., Foehr, E., Han, V., Lu, S., Kwon, H., LeFevour, A., Chakraborty-Sett, S., and Greene, W.C. 2006. NF- $\mathrm{B} /$ Rel regulates inhibitory and excitatory neuronal function and synaptic plasticity. Mol. Cell. Biol. 26: 7283-7298.

Paxinos, G. and Watson, C. 2005. The rat brain in stereotaxic coordinates, 5th ed. Elsevier Academic Press, San Diego.

Plotkin, M.D., Snyder, E.Y., Hebert, S.C., and Delpire, E. 1997. Expression of the Na-K-2Cl cotransporter is developmentally regulated in postnatal rat brain: A possible mechanism underlying GABA's excitatory role in immature brain. J. Neurobiol. 33: 781-795.

Regan, C.M. 2004. Cell adhesion molecules. In Memories are made of these: From messengers to molecules (eds. G. Riedel and B. Platt), pp. 564-579. Kluwer Academic/Plenum Publishers, London.

Romano, A., Freudenthal, R., Merlo, E., and Routtenberg, A. 2006. Evolutionarily-conserved role of the NF-кB transcription factor in neural plasticity and memory. Eur. J. Neurosci. 24: 1507-1516.

Rosenberger, J., Petrovics, G., and Buzas, B. 2001. Oxidative stress induces proorphanin FQ and proenkephalin gene expression in astrocytes through p38- and ERK-MAP kinases and NF-kB. $J$. Neurochem. 79: 35-44.

Rougon, G., Dubois, C., Buckley, N., Magnani, J.L., and Zollinger, W. 1986. A monoclonal antibody against meningococcus group B polysaccharides distinguishes embryonic from adult NCAM. J. Cell Biol. 103: 2429-2437.

Schneider, H., Pitossi, F., Balschun, D., Wagner, A., del Rey, A., and Besedovsky, H.O. 1998. A neuromodulatory role of interleukin-1 $\beta$ in the hippocampus. Proc. Natl. Acad. Sci. 95: 7778-7783.

Schreck, R., Rieber, P., and Baeuerle, P.A. 1991. Reactive oxygen intermediates as apparently widely used messengers in the activation of the NF-кB transcription factor and HIV-1. EMBO J. 10: 2247-2258.

Shen, W.H., Zhang, C.Y., and Zhang, G.Y. 2003. Antioxidants attenuate reperfusion injury after global brain ischemia through inhibiting nuclear factor-кB activity in rats. Acta Pharmacol. Sin. 24: 1125-1130.

Sheridan, G.K., Pickering, M., Moynagh, P.N., O'Connor, J.J., and Murphy, K.J. 2006. The pro-inflammatory cytokine TNF $\alpha$ upregulates nuclear factor-кB in selective neuronal subpopulations of the rat hippocampus. Proc. Br. Pharmacol. Soc. 3: 113 P.

Stork, O. and Welzl, H. 1999. Memory formation and the regulation of gene expression. Cell. Mol. Life Sci. 55: 575-592.

Taubenfeld, S.M., Stevens, K.A., Pollonini, G., Ruggiero, J., and Alberini, C.M. 2002. Profound molecular changes following hippocampal slice preparation: Loss of AMPA receptor subunits and uncoupled mRNA/protein expression. J. Neurochem. 81: 1348-1360.

Vernon, D.O., Garbuzova-Davis, S., Desjarlaisb, T., Singh Rasile, R., Sanberg, P.R., Willing, A.E., and Pennypacker, K.R. 2006. Reduced nuclear factor $\kappa$ B activation in dentate gyrus after active avoidance training. Brain Res. 1104: 39-44.

Wellmann, H., Kaltschmidt, B., and Kaltschmidt, C. 2001. Retrograde transport of transcription factor NF-кB in living neurons. J. Biol. Chem. 276: 11821-11829.

Whittingham, T.S., Lust, W.D., and Passonneau, J.V. 1984. An in vitro model of ischemia: Metabolic and electrical alterations in the hippocampal slice. J. Neurosci. 4: 793-802.

Received March 23, 2007; accepted in revised form June 15, 2007. 


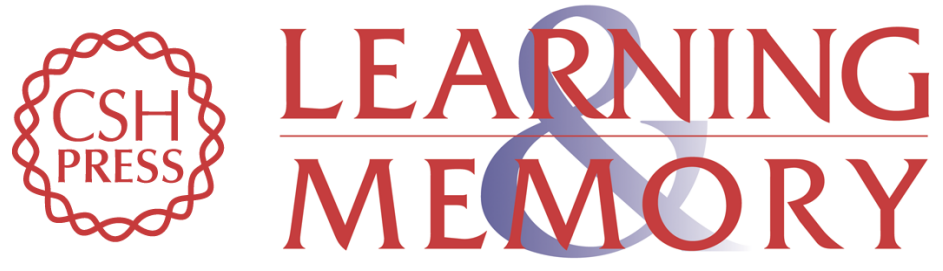

\section{NF-KB activity in distinct neural subtypes of the rat hippocampus: Influence of time and GABA antagonism in acute slice preparations}

Graham K. Sheridan, Mark Pickering, Clare Twomey, et al.

Learn. Mem. 2007, 14:

Access the most recent version at doi:10.1101//m.590007

References This article cites 41 articles, 11 of which can be accessed free at:

http://learnmem.cshlp.org/content/14/8/525.full.html\#ref-list-1

License

Email Alerting Receive free email alerts when new articles cite this article - sign up in the box at the Service top right corner of the article or click here. 